\title{
Sound production and pectoral spine locking in a Neotropical catfish (Iheringichthys labrosus, Pimelodidae)
}

\author{
Javier S. Tellechea ${ }^{1}$, Franco Teixeira-de Mello ${ }^{2,3}$, Iván Gonzalez-Bergonzoni2 ${ }^{2,3}$ \\ and Nicolás Vidal ${ }^{2}$
}

\begin{abstract}
Catfishes may have two sonic organs: pectoral spines for stridulation and swimbladder drumming muscles. The aim of this study was to characterize the sound production of the catfish Iheringichthys labrosus. The I. labrosus male and female emits two different types of sounds: stridulatory sounds $(655.8 \pm 230 \mathrm{~Hz})$ consisting of a train of pulses, and drumming sounds $(220$ $\pm 46 \mathrm{~Hz}$ ), which are composed of single-pulse harmonic signals. Stridulatory sounds are emitted during abduction of the pectoral spine. At the base of the spine there is a dorsal process that bears a series of ridges on its latero-ventral surface, and by pressing the ridges against the groove (with an unspecialized rough surface) during a fin sweep, the animal produce a series of short pulses. Drumming sound is produced by an extrinsic sonic muscle, originated on a flat tendon of the transverse process of the fourth vertebra and inserted on the rostral and ventral surface of the swimbladder. The sounds emitted by both mechanisms are emitted in distress situation. Distress was induced by manipulating fish in a laboratory tank while sounds were recorded. Our results indicate that the catfish initially emits a stridulatory sound, which is followed by a drumming sound. Simultaneous production of stridulatory and drumming sounds was also observed. The catfish drumming sounds were lower in dominant frequency than stridulatory sounds, and also exhibited a small degree of dominant frequency modulation. Another behaviour observed in this catfish was the pectoral spine locking. This reaction was always observed before the distress sound production. Like other authors outline, our results suggest that in the catfish I. labrosus stridulatory and drumming sounds may function primarily as a distress call.
\end{abstract}

Bagres podem apresentar dois órgãos sonoros: o espinho peitoral para o som peitoral ou estridulatório e o músculo sonoro da bexiga natatória. O objetivo deste trabalho foi caracterizar a produção de som no bagre Iheringichthys labrosus. Essa espécie emite dois sons diferentes, o som peitoral ou estridulatório $(655,8 \pm 230 \mathrm{~Hz})$ que consiste numa série de pulsos, e o som de tamboril $(220 \pm 46 \mathrm{~Hz})$ que é composto por sinais harmônicos de pulso simples. O som peitoral é emitido com o movimento do espinho da nadadeira peitoral. A base do espinho possui um processo dorsal que suporta uma série de cristas na sua superfície lateroventral, e ao pressionar as cristas contra o sulco (com uma superfície rugosa não especializada) durante o movimento de abertura da nadadeira, se produz uma série de pulsos curtos. O som de tamboril é produzido por um músculo sônico extrínseco, originado em um tendão plano preso ao processo transversal da quarta vértebra e inserido nas superfícies rostral e ventral da bexiga natatória. Os sons são emitidos por ambos os mecanismos em situação de estresse, a qual foi induzida através da manipulação dos peixes em um tanque no laboratório, enquanto os sons eram gravados. Nossos resultados indicam que o bagre emite primeiro o som peitoral e em seguida o som de tamboril. Também foi observada a produção simultânea dos sons estridulatório e de tamboril. O som de tamboril mostra uma frequência dominante mais baixa do que o som peitoral, e também apresenta um grau menor de modulação de frequência dominante. Isso pode estar relacionado com um som de cortejo, como verificado em outros peixes teleósteos. Outro comportamento observado nessa espécie de bagre é a capacidade de travar o espinho peitoral. Essa reação foi observada imediatamente antes da produção do som. Como descrevem outros autores, nossos resultados sugerem que em $I$. labrosus o som de estridulação e de tamboril funcionam como uma chamada de alarme.

Key words: Distress call, Sonic organs, Spine erection, Stridulation sound.

\footnotetext{
${ }^{1}$ Universidad de la Republica, Instituto de Biología, Departamento de Biología Animal, Laboratorio de Fisiología de la Reproducción y Ecología de Peces, Facultad de Ciencias, Iguá 4225, CP11400 Montevideo, Uruguay. jstellechea@gmail.com

${ }^{2}$ Universidad de la República, Grupo de Ecología y Rehabilitación de Sistemas Acuáticos, Departamento de Ecología y Evolución, CUREFacultad de Ciencias, Iguá 4225, CP 11400 Montevideo, Uruguay.

${ }^{3}$ Asociación Investigación y Desarrollo I+D, Iguá 4225, CP 11400 Montevideo, Uruguay.
} 


\section{Introduction}

Vocalization during social interactions is well known in numerous fish families (Fine et al., 1977; Myrberg, 1981; Ladich, 1997a; Tellechea et al., 2010, 2011). Catfishes are well known to produce sounds during courtship, agonistic behavior (Ladich \& Fine, 1994; Kaatz, 1999), and in response to disturbance (Fine et al., 1997; Heyd \& Pfeiffer, 2000; Fine \& Ladich, 2003). The first contexts in which sound production was registered were various distress situations, e.g. when fish were hand-held or caught (Ladich, 1997b). Systematic studies on sound producing abilities of fish subjecting animals to a variety of stressful stimuli demonstrated that acoustic signals are widespread in teleosts (Fish et al., 1952; Fish \& Mowbray, 1970).

Representatives of several catfish families possess two sonic mechanisms (Sorensen, 1895). One is sound produced by stridulation, caused by very small bony ridges located on the proximal end of the pectoral fin spine that is rubbed against the wall of the spinal fossa (Fine et al., 1997). The other is produced by swimbladder drumming muscles, which are absent in several catfish families (Siluridae, Ictaluridae, Locariidae, Callichthyidae). Contrary to the sonic mechanism of the pectoral spine, swimbladder mechanisms are very diverse and characteristic by family (Ladich, 1997b). Stridulatory sounds in catfish have been observed during agonistic encounters in undisturbed aquarium populations (Kaatz, 1999).

The pectoral spines of catfish are thought to deter predation through warning behavior and by increasing the effective size of the catfish (Endler, 1986; Fine \& Ladich 2003). Bosher et al. (2006) document that catfish pectoral spines can harm or kill predators, but there is no experimental support on the role of the pectoral spine in deterring predation. Recher \& Recher (1968) show that there is an increase on the rate of escape of prey from avian predators related to the presence of spines, but did not describe the use of the spines as an active defense mechanism. It has also been postulated that stridulation sounds could warn the predator of the spine (Sorensen, 1895), and that these sounds may have an aposematic function (Kaatz, 1999).

The "trompudo" Iheringichthys labrosus (Lütken, 1874) belongs to the Pimelodidae, a Neotropical catfish family characterized by the presence of three pairs of babels, well developed adipose fin, and presence or absence of pectoral and dorsal fin spines. This family consists of 31 described genera with more than 85 species (de Pinna, 1998; Nelson, 2006). Iheringichthys labrosus inhabits the La Plata River Basin, in the Paraná and Uruguay rivers (Abes et al., 2001). In reservoirs of the Paraná River basin, I. labrosus was considered a partial spawner with possibly multiple egg batches. The reproductive activity was reported to be throughout the year in the reservoir, with a maximum peak of mature individuals from October to January, and the spawning season from February to May (Santos et al., 2004).

In the middle and lower Uruguay River, I. labrosus is one of the most abundant catfish (Teixeira-de Mello et al., 2009) with a size range of $6.4-24.5 \mathrm{~cm}$, although not commercially important in regional fisheries (Teixeira-de Mello et al., 2009).

The aim of this study was to record and characterize the sounds emitted by I. labrosus and describe the functional morphology of its sound production mechanisms, that involve pectoral spines and muscles associated to the swimbladder.

\section{Material and Methods}

Fish ( $\mathrm{n}=30$ ) varying from five to $55 \mathrm{~cm}$ in total length were collected with a multi-mesh nets in April 2008 in three sites of lower Uruguay River: Nuevo Berlin, Yaguarete Bay, and Las Cañas, all in Rio Negro, Uruguay. Specimens were maintained alive in the laboratory for a week in $300 \mathrm{~L}$ tanks with river water at a temperature ranging $15-17^{\circ} \mathrm{C}$, as measured on the collection site. Each fish was captured with a hand net and placed at a distance of 1 meter from an underwater hydrophone in another $50 \mathrm{~L}$ tank for recording. After each recording, fish were killed with an overdose of anesthetics (a solution of 2-Phenoxy-Ethanol, $1 \mathrm{ml} \mathrm{l}^{-1}$ ), when its total length (cm) was measured and its sex was determined. Additionally, five males and five females were dissected to describe and analyze sound production structures.

Another experiment was performed in the field at Las Cañas during two hours at night time. This consisted of placing a 20 $\mathrm{m}$ length gillnet parallel to the river margin, with a hydrophone set at $2 \mathrm{~m}$ from the midpoint of the net, aiming to record the sound produced by the fish when they were caught.

Recordings were made with a hydrophone built in the laboratory (sensitivity- $40 \mathrm{~dB}$ re: $1 \mu \mathrm{Pa}$ and linear from 20 $\mathrm{Hz}$ and $60 \mathrm{kHz}$ ) on a digital recorder TASCAM HD-P2, with a sampling frequency of $44.1 \mathrm{kHz}$. Simultaneously, a video camera (Canon A 80) recorded sound and fish movements in order to determine if sounds were produced during abduction or adduction movements of the pectoral spine. Sound analysis was performed using Audacity free software, version 1.2.3. Power spectra were calculated using a 1024 point Fast Fourier Transform (FFT) with a Hanning window.

The following parameters were determined: train duration, number of sounds, sound duration, pulse period and dominant frequency. Male and female sound characteristics were compared using Student's unpaired t test (Sokal \& Rohlf, 1995), with statistical significance of $p=0.05$. All analyses were carried out using PAST free statistical software package, version 1.95 (Hammer et al., 2001).

\section{Results}

\section{Sound production mechanisms}

The catfish Iheringichthys labrosus emitted two different sounds, one produced by the pectoral spines (or stridulatory sound), and a drumming sound, which were emitted by both males and females. 
The pectoral sound was produced during spine abduction. The pulse sound was emitted during the abduction of one pectoral fin spine. Series of sounds were produced by abducting the pectoral fins alternately. The fish could also move pectoral fins silently or locking spines in an abducted position. Fish dissections allowed us to observe that the base of the spine has a dorsal process that bears a series of ridges on its ventrolateral surface. By pressing the ridges against the groove (with an unspecialized rough surface) during a fin sweep a series of short pulses of sound was produced. This sound can be produced artificially by moving the pectoral spine against the bones of the pectoral girdle, imitating the way the fish does it. This suggests that this sound results from a dorsal process on the spine rubbing against the series of ridges.

The specimens dissections also showed that I. labrosus produces drumming sounds with an extrinsic swim bladder muscle. This sonic muscle originates on a flat tendon of the transverse process of the fourth vertebra that inserts on the rostral and ventral surfaces of the swimbladder.

\section{Stridulatory sound}

Stridulatory sound consisted of a series of pulses and was emitted underwater and in the air when fish were held by the dorsal fin or immobilized (Fig. 1). Descriptive statistical values for the sound characteristics are shown in Table 1. In the $300 \mathrm{~L}$ tank, where all live specimens were kept together,

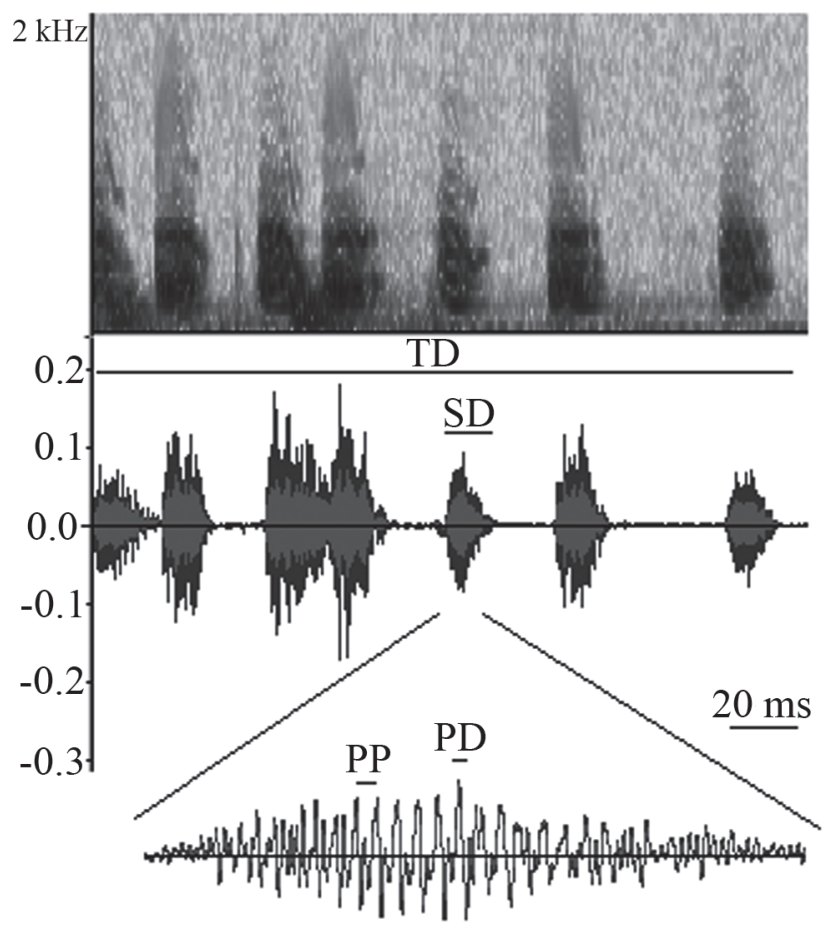

Fig. 1. Sonogram (top) and oscillogram (below) of pectoral sounds illustrating sound characteristics measured. $\mathrm{TD}=$ train durations; $\mathrm{SD}=$ sound duration; $\mathrm{PP}=$ pulse period; $\mathrm{PD}=$ pulse durations.
Table 1. Acoustical variables for pectoral sound, $\mathrm{ms}=$ milliseconds, $\mathrm{Hz}=$ Hertz. Number of sounds analyzed $\mathrm{n}=152$, pulses number analyzed $\mathrm{n}=672$.

\begin{tabular}{cc}
\hline Acoustical variables & Mean $( \pm \mathrm{SD})$ \\
\hline Train duration $(\mathrm{ms})$ & $960 \pm 365$ \\
Number of sounds & $3.25 \pm 2.7$ \\
Sound durations $(\mathrm{ms})$ & $17.06 \pm 0.47$ \\
Pulse period $(\mathrm{ms})$ & $0.07 \pm 0.05$ \\
Pulse durations $(\mathrm{ms})$ & $1.34 \pm 0.21$ \\
Dominant frequency $(\mathrm{Hz})$ & $655.80 \pm 230$ \\
\hline
\end{tabular}

no stridulatory sounds were emitted. However, we did notice that these sounds were emitted when the fish were entangled in a net (Fig. 2). No differences between male and female sounds were found for all variables analyzed: train duration $(\mathrm{p}=0.79)$, number of sounds $(\mathrm{p}=0.55)$, sounds duration $(\mathrm{p}=$ $0.73)$, pulse period $(p=0.20)$, pulse duration $(p=0.18)$, and dominant frequency $(\mathrm{p}=0.81)$.

This type of pectoral sound was also recorded when $I$. labrosus individuals were entangled in the net on the river (Fig. 2). The sound recorded in the field was the same as heard in the $50 \mathrm{~L}$ laboratory tank. Given the similarity between the calls recorded in the net and those recorded previously in the laboratory tank, we could predict the presence of $I$. labrosus specimens entangled and the rough quantity of specimens before actually seeing the fish in the net.

\section{Drumming sound}

Drumming sound was emitted both underwater and in the air, and was produced immediately after or simultaneously with stridulatory sounds. Sometimes drumming sounds were emitted independently of the stridulatory sounds. The drumming sounds were low frequency harmonic signals built up of single pulses (see ocillograms in Fig. 3), and also exhibit a small degree of frequency modulation. Mean acoustical variables of drumming sound are shown in Table 2.

No differences between male and female sounds were found for all variables analyzed: train duration $(p=0.74)$, number of sounds $(\mathrm{p}=0.40)$, sounds duration $(\mathrm{p}=0.71)$, pulse period $(p=0.29)$, pulse duration $(p=0.25)$, and dominant frequency $(p=0.48)$. Drumming sounds produced by swimbladder muscles were not heard or recorded during the experiment with the net in the river.

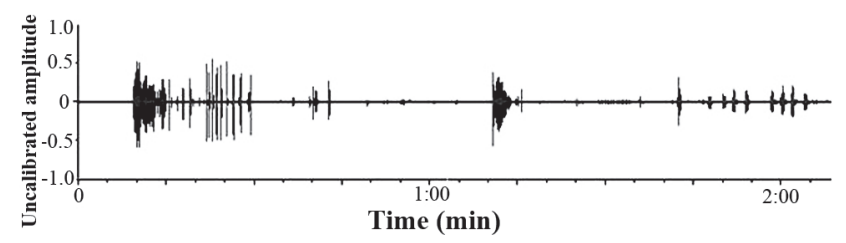

Fig. 2. Oscillogram of pectoral sound (all pulses in the oscillogram) emitted by Iheringichthys labrosus caught in the net in field. 


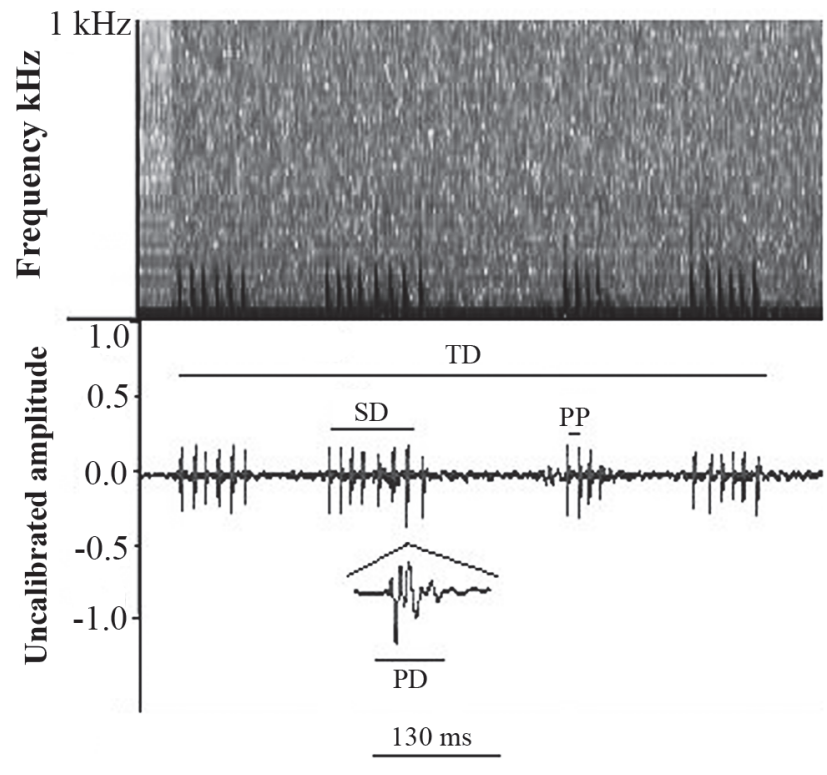

Fig. 3. Sonogram (top) and oscillogram (below) swimbladder drumming sounds recorded underwater illustrating sound characteristics measured. $\mathrm{TD}=$ train durations; $\mathrm{SD}=$ sound duration; $\mathrm{PP}=$ pulse period; $\mathrm{PD}=$ pulse durations.

\section{Spine erection and locking}

Other behaviour observed in this catfish was the locking capacity of the pectoral spine. This reaction was always observed before the sound production, when the fish was being handled; once the fish unlocked the fin spine the sound production begun. The spine, a stout and sharp modified fin ray composed of dense bone tissue, has strong serrated dentations along its posterior and anterior edges.

\section{Discussion}

This study documents the sound production by Iheringichthys labrosus in the Uruguay River (La Plata Basin, South America). Both male and female exhibit pectoral stridulation and swimbladder drumming sounds when held by the dorsal fin under water, or somehow immobilized or in distress condition. Among teleosts, catfish are unique in possessing two sonic organs, and there are some basic differences in the known morphological variability of both types of organs (Ladich, 1997b).

In catfishes, differences in the pectoral sound-producing apparatus are mainly restricted to the relative size of the pectoral spines. Swimbladder mechanisms, on the other hand, differ widely in the insertion and origin of extrinsic muscles as well as in the vibrating structures (Ladich, 1997b). The general morphology of the structures associated to the pectoral spines that produce sound is very similar in many species (Fine et al., 1997; Diogo et al., 2001). In addition to the abductor and adductor muscles, there are other muscles such as arrector dorsalis and arrector ventralis, involved in the movement of the spine and sound production (Fine et al., 1996; Kaatz, 1999;
Table 2. Acoustical variables for drumming sound, $\mathrm{ms}=$ milliseconds, $\mathrm{Hz}=$ Hertz. Number of sounds analyzed $\mathrm{n}=98$, pulses number analyzed $n=263$.

\begin{tabular}{cc}
\hline Acoustical variables & Mean $( \pm \mathrm{SD})$ \\
\hline Train duration $(\mathrm{ms})$ & $1008 \pm 20$ \\
Number of sounds & $4.20 \pm 1.70$ \\
Sound durations $(\mathrm{ms})$ & $120 \pm 2.32$ \\
Pulse period $(\mathrm{ms})$ & $6 \pm 1.21$ \\
Pulse durations $(\mathrm{ms})$ & $1.30 \pm 1.20$ \\
Dominant frequency $(\mathrm{Hz})$ & $220 \pm 46$ \\
\hline
\end{tabular}

Heyd \& Pfeiffer, 2000; Fine \& Ladich, 2003). The pulse sound is probably not produced by singles ridges contacting the cleithral surface, even though we originally thought this was the case. There are recent studies that indicate that the pulses are in fact made up of a series of jerky movements of the spine, using several muscles (Parmentier et al., 2010).

In Iheringichthys labrosus the sound is produced only during the abduction of the pectoral spine, whereas in other families the sounds may be produced during abduction and adduction of such structures (e.g. some members of Aspredinidae and Ictaluridae; Gainer, 1967; Rigley \& Muir, 1979). Fine et al. (1996) stated that stridulation was typically produced by pectoral fin abduction in Ictalurus punctatus (Ictaluridae). The comparison of different species clearly shows that ridges on the dorsal process of the proximal end of pectoral spine are necessary to produce sounds (Parmentier et al., 2010). The pectoral sound registered in I. labrosus was caused by various distress situations, e.g. when fish were hand-held or caught both underwater; some pimelodid catfishes show the same type of behaviour (Ladich \& Fine, 2006).

Swimbladder drumming sound in I. labrosus is produced with the extrinsic swim bladder muscle (Ladich \& Fine, 1994). In pimelodids, drumming muscles originate from a transverse process of the fourth vertebra and are inserted ventrally on the swimbladder (Schachner \& Schaller, 1981; Ladich \& Fine, 1994). However, drumming muscles are not universally present in pimelodids and thus it is not a characteristic of the family (Ladich \& Fine, 2006). Bridge \& Haddon (1889) observed atrophy and degeneration of the swim bladder in many catfish species that lack sonic muscles.

Drumming sounds were also emitted in distress situation underwater and in the air. In contrast to stridulatory sounds, drumming sounds were low frequency harmonic signals built up of singles pulses, and similar to the observed in Pimelodus blochii and P. pictus (Ladich, 1997b). Pectoral sound and drumming sound were emitted in distress situations, like in other catfishes (Ladich \& Fine, 2006). In our experiments the drumming sound was produced after or simultaneously with pectoral sounds, and sometimes drumming sounds were emitted without stridulatory sounds; the same occurs in $P$. blochii and P. pictus (Ladich, 1997b).

Drumming sounds also exhibit a small degree of frequency modulation, a feature relatively unusual in fishes compared to birds and mammals (Fine et al., 1977). Long spawning calls of male haddocks Melanogrammus aeglefinus exhibit distinct 
frequency modulations (Hawkins \& Rasmussen, 1978; Hawkins, 1986) that reflect changes in pulse repetition rates among species of mormyrids, catfishes, cods and toadfish, and are perhaps due to muscle fatigue or to different levels of excitement (Ladich, 1997b).

Other studies reveal that changes in fundamental frequencies are related to water temperature (Brantley \& Bass, 1994). This frequency modulation could be associated to the reproductive behaviour, like in other fishes with drumming sounds (Ladich \& Fine, 2006, Tellechea et al., 2010; 2011), so we think that drumming sound in I. labrosus may be used during the spawning as a courtship sound by males; nevertheless, more studies are necessary to test this hypothesis.

In addition to sound production in I. labrosus, the pectoral spine can be locked. This reaction was always shown before sound production. Spine locking and stridulation are opposite behaviours, and a fish cannot accomplish both simultaneously. The junction of the spine forms a modified joint with the pectoral girdle, and the mechanics of this junction allow the spine to be bound and locked, making it resistant to opposing forces (Fine et al. 1997; Fine \& Ladich, 2003). The pectoral spines of catfishes are thought to deter predation through warning behaviour and by increasing the effective size of the catfish (Endler, 1986; Fine \& Ladich, 2003). The study of Bosher et al. (2006) seems to be the only experimental evidence that indicates that catfish pectoral spines can harm or kill predators. Bosher et al. (2006), in a study involving the channel catfish ( $I$. punctatus) state that the stridulation sounds do not carry a warning function, and the stridulatory behaviour is ineffective for warning predation by largemouth bass. Therefore, it is likely that stridulatory sounds serve as a distress call that could potentially summon other predators and increase the emitter's chances of escape (Bradbury \& Vehrencamp, 1998).

We do not know if diversity in sonic organs results in differences in sonic communication and if sounds are produced in similar contexts among catfishes. Abu-Giderini \& Nasr (1973) mentioned that Synodontis schall (Mochokidae) grunt in various defense and fright situations and that these fish only produce creak sounds when handled. Schacher \& Schaller (1981) described drumming sounds during threatening behavior in the heptapterid catfish Rhamdia sebae (= Rhamdia quelen) and stridulatory sounds during defense behavior.

Like other authors outline, our results suggest that in $I$. labrosus stridulation and drumming sounds function as a distress call, and that drumming sound could also be used during spawning or courtship behavior. Moreover, the spine locking mechanism could be make the catfish more difficult to be swallowed by the predator, but do not seems to be effective in deterring capture (Bosher et al. 2006).

\section{Acknowledgements}

For their invaluable collaboration we wish to thank to R. Ballabio, D. Larrea, L. Rover and J. Tana for data collection; L. M. de Carvalho and C. Oddone for the Portuguese translation; and G. P. Roman for the revision of the English text. We are grateful to IDEA WILD for donating the recording equipament. FTM received support from the SNI (Agencia Nacional de Investigación e Innovación, ANII, Uruguay).

\section{Literature Cited}

Abes, S. S., A. A. Agostinho, E. K. Okada \& L. C. Gomes. 2001. Diet of Iheringichthys labrosus (Pimelodidae, Siluriformes) in the Itaipu Reservoir, Paraná River, Brazil-Paraguay. Brazilian Archives of Biology and Technology, 44: 101-105.

Abu-Gideirini, J. B. \& D. H. Nasr. 1973. Sound production by Synodontis schall (Bloch-Schneider). Hydrobiologia, 43: 415-428.

Bosher, B. T., S. H. Newton \& M. L. Fine. 2006. The Spines of the Channel Catfish, Ictalurus punctatus, as an Anti-Predator Adaptation: an Experimental Study. Ethology, 112: 188-195.

Bradbury, J. W. \& S. L. Vehrencamp. 1998. Principles of Animal Communication. Sunderland, Massachusetts, Sinauer Associates, Inc. 882 p.

Brantley, R. K. \& A. H. Bass. 1994. Alternative male spawning tactics and acoustic signals in the plainfin midshipman fish Porichthys notatus Girard (Teleostei, Batrachoididae). Ethology, 96: 213-232.

Bridge, T. W. \& A. C. Haddon. 1889. Contribution to the anatomy of fishes. I. The airbladder and Weberian ossicles in the Siluridae. Proceedings of the Royal Society of London B Biological Sciences, 46: 209-227.

Diogo, R., C. Oliveira \& M. Chardon. 2001. On the osteology and myology of catfish pectoral girdle, with a reflection on catfish (Teleostei: Siluriformes) plesiomorphies. Journal Morphology, 249: 100-125.

Endler, J. A. 1986. Defence against predators. Pp. 109-134. In: Feder, M. E. \& G. V. Lauder (Eds). Predator-Prey Relationships: Perspectives and Approaches from the Study of Lower Vertebrates. Chicago, University of Chicago Press.

Fine, M. L., J. P. Friel, D. McElroy, C. B. King, K. E. Loesser \& S. Newton. 1997. Pectoral spine locking and sound production in the channel catfish (Ictalurus unctatus). Copeia, 1997: 777-790.

Fine, M. L. \& F. Ladich. 2003. Sound production, spine locking and related adaptations. Pp. 249-290. In: Arratia, G., B. G. Kapoor, M. Chardon \& R. Diogo (Eds). Catfishes. Science Publ., Enfield, NH, vol. 1.

Fine, M. L., D. McElroy, J. Rafi, C. B. King, K. E. Loesser \& S. Newton. 1996. Lateralization of pectoral sound production in the channel catfish. Physiology and Behavior, 60: 753-757.

Fine, M. L., H. E. Winn \& B. L. Olla. 1977. Communication in fishes. Pp. 472-518. In: Sebeok, T. A. (Ed.). How Animals Communicate. Bloomington, Indiana University Press.

Fish, M. P., A. S. Kelsey \& W. H. Mowbray. 1952. Studies on the production of underwater sound by north Atlantic coastal fishes. Journal of Marine Research, 11: 180-193.

Fish, M. P. \& W. H. Mowbray. 1970. Sounds of Western North Atlantic fishes: A reference file of biological underwater sounds. The John Hopkins Press, Baltimore.

Gainer, H. 1967. Neuromuscular mechanisms of sound production and pectoral pine locking in the banjo catfish Bunocephalus species. Physiological Zoology, 40: 296-306.

Hammer,Ø., D. A. T. Harper \& P.D. Ryan. 2001. PAST: Paleontological Statistic software package for education and data analysis. Paleontologia Electronica, 4: 1-9.

Hawkins, A. D. 1986. Underwater sound and fish behaviour. Pp. 
114-115. In: Pitcher T. J. (Ed.). The Behaviour of Teleost Fishes. London, Croom Helm.

Hawkins, A. D. \& K. J. Rasmussen. 1978. The calls of gadoid fishes. Journal of the Marine Biological Association of the United Kingdom, 58: 891-911.

Heyd, A. \& W. Pfeiffer. 2000. Über die Lauterzeugung der Welse (Siluroidei, Ostariophysi, Teleostei) und ihren Zusammenhang mit der Phylogenese und der Schreckreaktion. Revue suisse de Zoologie, 107: 165-211.

Kaatz, I. M. 1999. The behavioral and morphological diversity of acoustic communication systems in a clade of tropical catfishes (Pisces: Siluriformes, Super Family Arioidei). Unpublished Ph.D. Dissertation. University Syracuse, New York.

Ladich, F. 1997a. Agonistic behaviour and significance of sounds in vocalizing fish. Marine and Freshwater Behaviour and Physiology, 29: 87-108.

Ladich, F. 1997b. Comparative analysis of swimbladder (drumming) and pectoral (stridulation) sounds in three families of catfishes. Bioacoustics, 8: 185-208.

Ladich, F. \& M. L. Fine 1994. Localization of swimbladder and pectoral motoneurons involved in sound production in pimelodid catfish. Brain Behavior and Evolution, 44: 86-100.

Ladich, F. \& M. L. Fine. 2006. Sound generating mechanisms in fishes: A unique diversity in vertebrates Pp. 3-43. In: Ladich, F., S. P. Collin, P. Moller \& B. G. Kapoor (Eds.). Communication in Fishes. Enfield, New Hampshire, Science Publishers Inc.

Myrberg, A. A. Jr. 1981. Sound comunication and interception in fishes. Pp. 395-426. In: Tavolga, W. N., A. N. Popper \& R. R. Fay (Eds). Hearing and Sound Communication in Fishes. Berlin, Springer Verlng.

Nelson, J. S. 2006. Fishes of the world. New York, John Wiley and Sons, Inc. 4th ed., 601p.

Parmentier, E., G. Fabri, I. Kaatz, N. Decloux, S. Planes \& P. Vandewalle. 2010. Functional study of the pectoral spine stridulation mechanism in different mochokid catfishes. The Journal of Experimental Biology, 213: 1107-1114

de Pinna, M. C. C. 1998. Phylogenetic relationships of neotropical Siluriformes (Teleostei: Ostariophysi): historical overview and synthesis of hypotheses. Pp. 279-330. In: Malabarba, L. R.,
R. E. Reis, R. P. Vari, Z. M. S. Lucena \& C. A. S. Lucena (Eds.). Phylogeny and Classification of Neotropical Fishes. Porto Alegre, Edipucrs, 603p.

Recher, H. F. \& J. A. Recher. 1968. Comments on the escape of prey from avian predators. Ecology, 49: 560-562.

Rigley, L. \& J. Muir. 1979. The role of sound production by the Brown bullhead Ictalurus nebulosus. Proceedings of the Pennsylvania Academy of Science, 53: 132-134.

Santos, J. E., E. Rizzo, N. Bazzoli \& G. B. Santos. 2004. Reproduction of catfish Iheringichthys labrosus (Lütken, 1874) (Pisces, Siluriformes) from Furnas reservoir, Minas Gerais, Brazil. Revista Brasileira de Zoologia, 21: 193-200.

Schachner, G. \& F. Schaller. 1981. Schallerzeugung und Schallreaktionen beim Antennenwels (Mandim) Rhamdia sebae sebae Val. Zoologische Beitraege, 27: 375-392.

Sokal, R. R. \& F. J. Rohlf. 1995. Biometry: the principles and practice of statistics in biological research. New York, W. H. Freeman and Company. 850p.

Sorensen, W. 1895. Are the extrinsic muscles of the air-bladder in some Siluroidae and the "elastic spring" apparatus of others subordinate to the voluntary production of sounds? What is, according to our present knowledge, the function of the weberian ossicles? Journal of Anatomic and Physiology, 29: 109-139.

Teixeira-de Mello, F., N. Vidal, I. Gonzalez-Bergonzoni \& C. Iglesias. 2009. Length-weight relationship of eight fish species from the lower section of the Uruguay River (Río Negro, Uruguay). Journal of Applied Ichthyology, 25: 128-129.

Tellechea S. J., C. Martinez, M. L. Fine \& W. Norbis. 2010. Sound production in whitemouth croaker (Micropogonias furnieri Sciaenidae) and relationship between fish size and disturbance call parameters. Environmental Biology of Fishes, 89: 163-172.

Tellechea, J. S., W. Norbis, D. Olsson \& M. L. Fine. 2011. Calls of the black drum (Pogonias cromis: Sciaenidae): geographical differences in sound production between northern and southern hemisphere populations. Journal Experimental Zoology, 315A: 48-55.

Submitted December 26, 2010 Accepted August 25, 2011 Published December 26, 2011 